\title{
ACADEMICIANS' VIEWS ON MEDICAL TOURISM NURSING AND ITS EDUCATIONAL STRUCTURE: A MIXED-METHOD STUDY ${ }^{(1)}$
}

\section{MEDIKKAL TURIZM HEMŞIRELIĞİNIN EĞITIMM YAPISI VE AKADEMISYYENLERINN GÖRÜŞLERİ: BİR KARMA YÖNTEM ÇALIŞMASI}

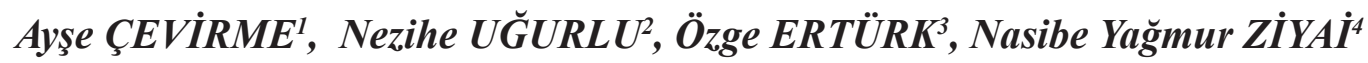

${ }^{1}$ Sakarya University, School of Health, Public Health Nursing, Sakarya / Turkey

${ }^{2}$ Muğla Sıtkı Koçman University, Muğla School of Health, Mental Health and Psychiatric Nursing, Muğla / Turkey

${ }^{3}$ Sakarya University, School of Health, Public Health Nursing, Sakarya / Turkey Orcid No:0001-9238-490X

${ }^{4}$ Sakarya University, School of Health, Public Health Nursing, Sakarya / Turkey

ORCID ID: 0000-0001-7116-2523', 0000-0003-2860-1169², 0000-0001-9238-490X

0000-0003-0175-23034

Öz: Amaç: Bu çalışmanın amacı, akademisyenlerin tıbbi turizm hemşireliği ve eğitim yapısı hakkındaki görüşlerini belirlemektir. Yöntem: Veriler, hem niceliksel hem de niteliksel yaklaşımları birleştiren karma bir yöntem kullanılarak toplanmıştır. Nicel ve nitel veriler sırasıyla 46 ve 9 akademisyenden toplanmıştır. 15 maddeden oluşan yapılandırılmış bir anket kullanılmış ve veri toplamak için geniş kapsamlı görüşmeler yapılmıştır. Görüşmeler sırasında kapsamlı notlar alındı ve kaydedildi. Bulgular: Akademisyenlerin medikal turizm hemşireliği ile ilgili yeterlilikler ve eğitsel duruma dair 6 tema 33 alt tema belirlendi. Araştırmada en sık kullanılan alt tema medikal turizm hemşireliğinin eğitim yapılanmasında düzenlemelere ihtiyaç olduğudur. Sonuç: Medikal turizm hemşireliği ile ilgili ülkemizde yapılan çalışmaların yetersizliği, medikal turizm ile ilgili eğitsel, akademik etkinlikler ve yasal düzenlemelere ihtiyaç olduğu, yabancı hemşire istihdamına gerek olmadığı şeklindedir.

Anahtar Kelimeler: Akademisyen görüşleri, eğitim yap1s1, medikal turizm, karma yöntem, hemşirelik
Abstract: Aim: The aim of this study is to determine academics' views on medical tourism nursing and its educational structure. Method: Data were collected using a mixed method combining both quantitative and qualitative approaches. Quantitative and qualitative data were collected from 46 and 9 academics, respectively. A structured questionnaire consisting of 15 items was used, and in-depth interviews were carried out to collect data. In-depth interviews were recorded and extensive notes were taken during interviews. Findings: 6 themes and 32 sub-themes regarding academics' views on qualifications and educational levels related to medical tourism nursing emerged. Some of the sub-themes are as follows: The education system of medical tourism nursing needs regulations. Conclusion: The number of studies on medical tourism nursing in Turkey is limited. There is a need for educational/ academic activities and legal arrangements related to medical tourism. There is no need for the employment of foreign nurses.

Key Words: Academics' views, educational structure, medical tourism, mixed method, nursing

Doi: $10.17363 /$ SSTB.2019.32.3

(1) Sorumlu Yazar, Corresponding Author: Ayşe ÇEVIRME “Doç. Dr., Assoc. Prof”, Sakarya University, School of Health, Public Health Nursing, Sakarya / Turkey, acevirme@sakarya.edu.tr, Gelis Tarihi / Received: 11.02.2019, Kabul Tarihi / Accepted: 15.11.2019, Makalenin Türü: Type of Article: (Araştırma - Uygulama; ResearchApplication) Çıkar Çatışması, Yok - Conflict of Interest, No, Etik Kurul Raporu veya Kurum İzin Bilgisi-Ethical Board Report or Institutiunal Approval, Yok/No 
International Refereed Academic Journal of Sports, Health and Medical Sciences

October - November - December Issue: 33 Fall Winter Semester Year: 2019

Uluslararası Hakemli Akademik Spor Sağlık ve Tıp Bilimleri Dergisi

Ekim - Kasım - Aralık Sayı: 33 Güz Kış Dönemi Yıl: 2019 ID:455 K:231

ISSN Print: 2146-8508 Online 2147-1711

(ISO 18001-OH-0090-13001706 / ISO 14001-EM-0090-13001706 / ISO 9001-QM-0090-13001706 / ISO 10002-CM-0090-13001706) (TRADEMARK)

(2015/04315- 2015-GE-18972)

\section{INTRODUCTION}

Medical tourism, also referred to as medical travel, health tourism, medical outsourcing or global healthcare, is defined as seeking medical care outside one's country of residence. This care may include medical treatments, diagnostic or surgical procedures or dental care.

Countries and centers with both high success rates and price advantages appeal to medical tourists (BookmanandBookman,2007:1-29; Çevirme et al.,2014:44-58). Evans (2008:1089-1095) reports that medical tourism was a $\$ 60$ billion industry worldwide in 2006. Turkey is also one of the attractive destinations for medical tourism. The number of international patients coming to Turkey has been increasing every year, especially since 2010 (Evans,2008:1089-1095; KayaandBüyükkasap,2005:367-380).

Medical tourism has also brought about some issues such as medical care trends, and treatment quality and safety. Medical tourists do not only benefit from high-tech medical facilities and treatment but also attach importance to the quality and reliability of care that directly affects recovery and increases the quality of life (Ben-Natan et al.,2009; Aydın et al.,2011). Care is, undoubtedly, one of the most important services provided by nurses. Healthcare is a whole system which funda- mentally relies on both dimensions of treatment and care.

Standard training and practices in the core curriculum may not be sufficient in terms of nursing care and other professional services offered to medical tourists for medical purposes.

Curricula and instructional programs should be restructured as soon as possible and nursing students should be provided with opportunities to develop graduate profiles that can be integrated into changing health movements so that they feel qualified and confident enough to assume their role in the field of medical tourism. It is, therefore, crucial to factor in the views and attitudes of academics and instructors involved in decision making processes in order to undertake regulations in nursing education curriculum and to restructure the teaching/learning approach aimed at enabling nursing students to acquire professional qualifications. The construction of the educational process in this manner can only be evaluated by educators themselves.

\section{AIM}

The aim of this study is to investigate academics' views on the importance placed on medical tourism nursing in the curriculum in terms of vocational qualifications and to contribute to the scientific solution of the problem according to these views. To this end, the 
International Refereed Academic Journal of Sports, Health and Medical Sciences October - November - December Issue: 33 Fall Winter Semester Year: 2019

Uluslararası Hakemli Akademik Spor Sağlık ve Tıp Bilimleri Dergisi

Ekim - Kasım - Aralık Sayı: 33 Güz Kış Dönemi Yıl: 2019 ID:455 K:231

ISSN Print: 2146-8508 Online 2147-1711

(ISO 18001-OH-0090-13001706 / ISO 14001-EM-0090-13001706 / ISO 9001-QM-0090-13001706 / ISO 10002-CM-0090-13001706) (TRADEMARK)

qualitative dimension of this study sought answers to sub-problems determined based on quantitative data.

\section{MATERIAL AND METHOD}

Data were collected using a mixed method including both qualitative and quantitative dimensions, and the study was carried out in two stages.

\section{Data Collection}

Survey method was used as the main research method, and a structured questionnaire was used to collect data to construct the sub-problems. The questionnaire was developed based on an extensive review of the literature with particular attention to previous survey instruments and theoretical frameworks that addressed the subject matter in question.

\section{Sample Population}

Quantitative Dimension: The study population consisted of academics of vocational schools of health providing nursing education at the undergraduate level of universities affiliated to the Higher Education Council (HEC) ${ }^{1}$. The faculty of nursing, faculty of health sciences, vocational health high school and college of health sciences (vocational schools of health in Turkey) were taken as strata and stratified sampling method was used to select a random sample from each stratum. The study was carried out with 4 aca- demics institutions who voluntarily answered the questionnaire and provided feedback ${ }^{1}$.

Qualitative Dimension: Purposive sampling, which is one of the nonprobability sampling techniques, was used to select 10 academics from a vocational school of health, and phenomenological interviews were conducted with them. However, one of the participants withdrew from the study due to health problems, and therefore, the study was completed with 9 academics.

Quantitative data on medical tourism and nursing (Table 1) obtained through the questionnaire were used to identify the sub-problems of the qualitative part of the study. The questions that constituted the sub-problems and to which answers were sought were used as the data collection tool in the in-depth interviews performed in the qualitative part of the study.

Participants' responses to the interview questions were analyzed into themes and subthemes, and gathered together in Table 2 in the findings section in order to obtain consistent and conclusive results.

Data collection process was extended over a long-term period (from 09 July 2014 to 15 August 2017) and data collection sessions were scheduled at participants' convenience. Though the data collection started in 2014, three academics were able to participate in 


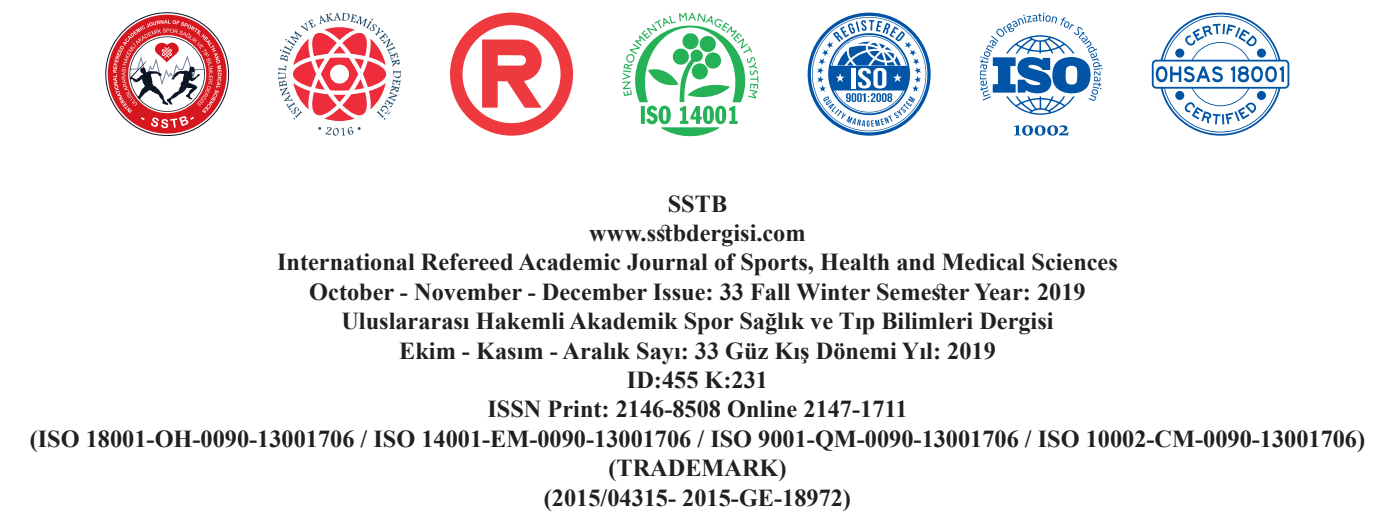

the study as late as 2017 due to their career plans. Therefore, reporting ended in January of 2017.

\section{Validity and Reliability of the Study}

Using both survey and interview methods provides us with the opportunity to determine themes underlying participants' responses during interviews based on survey data (ÖzdenandDurdu,1-187).

Using these two different methods is effective in terms of ensuring the reliability of the study. Participants' names were coded as A1,A2...A9 for confidentiality.

\subsection{Ethical consideration}

In the quantitative part of the study, participants were provided with a link to access the survey. The necessary permission was granted by the relevant institution for qualitative data collection. Two co-authors (Ö.K. and N.Y.Z.) obtained informed consent from participants and arranged interviews.

\section{Criteria for Inclusion in the Study}

Academics who are involved in curriculum development and decision making processes, and have the authority and capacity to give lectures were included in the study.

\section{Analysis}

Data were analyzed using the Statistical Package for Social Sciences (SPSS), version 16.0.
Numbers (n) and percentages (\%) were used to summarize the data. The difference in rates between participants' responses to 7 out of 15 items in the questionnaire was significant, therefore, the results obtained from those 7 items were converted into Table 1.

Analysis of Qualitative Data: In-depth interview data were analyzed using content analysis. An in-depth analysis was performed through interpretation and inference in order to investigate participants' views on nurses' qualifications/level of knowledge regarding medical tourism. The following steps were taken to collect data. Participants were interviewed. All interviews were recorded using an audiotape, and contemporaneous written notes were kept of each session. Prior to the analysis of the interviews, participants were ranked on an ordinal scale based on the time of their participation and their names were replaced with codes (A1, A2 etc.) to maintain confidentiality. Each interview lasted about 45-60 minutes. Transcripts were compared with the notes taken from each interview. All participants read and gave informed consent for the reevaluation of the data. Content analysis refers to a systematic, objective and numerical analysis to measure variables in a text (Vaismoradi et al.,2013:398-405). Data obtained from participants' responses to the survey were analyzed using content analysis methods (categorical and frequency analysis). In the categorical (key theme) analysis, 
SSTB

www.sstbdergisi.com

International Refereed Academic Journal of Sports, Health and Medical Sciences

October - November - December Issue: 33 Fall Winter Semester Year: 2019

Uluslararası Hakemli Akademik Spor Sağlık ve Tıp Bilimleri Dergisi

Ekim - Kasım - Aralık Sayı: 33 Güz Kış Dönemi Yıl: 2019

ID:455 K:231

ISSN Print: 2146-8508 Online 2147-1711

(ISO 18001-OH-0090-13001706 / ISO 14001-EM-0090-13001706 / ISO 9001-QM-0090-13001706 / ISO 10002-CM-0090-13001706) (TRADEMARK)

(2015/04315- 2015-GE-18972)

(1) in-depth interview data were coded and

(2) the dimensions of the categories (subthemes) were determined. 6 key themes and 32 sub-themes emerged from the data (Table 2).

\section{Limitations of the Study}

The findings are limited to the participants of this study, and therefore, are not generalizable to the academics of all schools of nursing. It is recommended that similar research be conducted in many faculties and colleges in the future.

\section{RESULTS}

\section{Quantitative Dimension}

$95.7 \%$ of participants are women, $61 \%$ are faculty members and $58.7 \%$ work in the faculties of health sciences. $34.78 \%$ of participants read articles, reviews etc. on medical tourism while $6.52 \%$ attend congresses, symposiums etc. $66 \%$ of academics think that the curriculum is insufficient while $89 \%$ think that new qualifications are needed in the field of nursing for medical tourism (Table 1). 
SSTB

www.sstbdergisi.com

International Refereed Academic Journal of Sports, Health and Medical Sciences

October - November - December Issue: 33 Fall Winter Semester Year: 2019

Uluslararası Hakemli Akademik Spor Sağlık ve Tıp Bilimleri Dergisi

Ekim - Kasım - Aralık Sayı: 33 Güz Kıs Dönemi Yıl: 2019 ID:455 K:231

ISSN Print: 2146-8508 Online 2147-1711

(ISO 18001-OH-0090-13001706 / ISO 14001-EM-0090-13001706 / ISO 9001-QM-0090-13001706 / ISO 10002-CM-0090-13001706) (TRADEMARK)

(2015/04315- 2015-GE-18972)

Table 1. Rates of Agreement of Academics With Qualifications And Educational Levels Related To Medical Tourism Nursing

\begin{tabular}{|c|c|c|c|c|c|c|}
\hline \multirow[b]{2}{*}{ Views } & \multicolumn{2}{|c|}{ I AGREE } & \multicolumn{2}{|c|}{ I DISAGREE } & \multicolumn{2}{|c|}{ TOTAL } \\
\hline & $\begin{array}{l}\text { Number } \\
\text { (n) }\end{array}$ & $\begin{array}{l}\text { Percent- } \\
\text { age }(\%)\end{array}$ & $\begin{array}{l}\text { Number } \\
\text { (n) }\end{array}$ & $\begin{array}{l}\text { Percent- } \\
\text { age }(\%)\end{array}$ & $\mathrm{N}$ & $\%$ \\
\hline $\begin{array}{l}\text { The medical tourism curriculum is sufficient } \\
\text { for the role and duties of nurses. }\end{array}$ & 11 & 24 & 35 & 66 & 46 & 100 \\
\hline $\begin{array}{l}\text { New qualifications (e.g. vocational English or } \\
\text { a second language) are required in the field of } \\
\text { nursing for medical tourism. }\end{array}$ & 41 & 89 & 5 & 11 & 46 & 100 \\
\hline $\begin{array}{l}\text { Nursing students are willing to work in the } \\
\text { field of medical tourism. }\end{array}$ & 40 & 87 & 6 & 13 & 46 & 100 \\
\hline $\begin{array}{l}\text { Nurses with a bachelor's degree are qualified } \\
\text { enough to treat patients coming from other } \\
\text { countries for medical purposes. }\end{array}$ & 14 & 30 & 32 & 70 & 46 & 100 \\
\hline $\begin{array}{l}\text { Legislative regulations should be established } \\
\text { to determine roles and duties of nurses in the } \\
\text { field of medical tourism. }\end{array}$ & 45 & 98 & 1 & 2 & 46 & 100 \\
\hline $\begin{array}{l}\text { The medical tourism and nursing curriculum } \\
\text { should be included only in the education } \\
\text { programs of universities located in regions } \\
\text { where only foreign patients are provided with } \\
\text { medical care. }\end{array}$ & 19 & 41 & 27 & 59 & 46 & 100 \\
\hline $\begin{array}{l}\text { Standardization and accreditation studies in } \\
\text { patient care are issues that should be addres- } \\
\text { sed by nurses in institutions where medical } \\
\text { services are provided. }\end{array}$ & 45 & 98 & 1 & 2 & 46 & 100 \\
\hline
\end{tabular}

\section{Qualitative Dimension}

All participants are women between the ages of 28 and 60 years (median age: 38.5 ). Table 2 shows the themes and sub-themes that emerged from the interviews. 6 themes and
32 sub-themes regarding academics' views on qualifications and educational levels related to medical tourism nursing were identified. The qualitative findings were interpreted with reference to quotes from participants, following the order of the themes. 


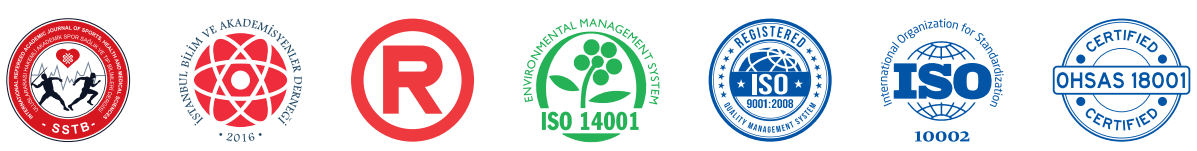

SSTB

www.sstbdergisi.com

International Refereed Academic Journal of Sports, Health and Medical Sciences

October - November - December Issue: 33 Fall Winter Semester Year: 2019

Uluslararası Hakemli Akademik Spor Sağlık ve Tıp Bilimleri Dergisi

Ekim - Kasım - Aralık Sayı: 33 Güz Kış Dönemi Yıl: 2019

ID:455 K:231

ISSN Print: 2146-8508 Online 2147-1711

(ISO 18001-OH-0090-13001706 / ISO 14001-EM-0090-13001706 / ISO 9001-QM-0090-13001706 / ISO 10002-CM-0090-13001706)

(TRADEMARK)

(2015/04315- 2015-GE-18972)

Table 2. Themes And Sub-Themes Regarding Academics' Views On Qualifications And Educational Levels Related To Medical Tourism Nursing

\begin{tabular}{|c|c|}
\hline Themes & Sub-themes \\
\hline \multirow{7}{*}{$\begin{array}{l}\text { 1. The position } \\
\text { of the course and } \\
\text { the adequacy of } \\
\text { its content }\end{array}$} & 1. In the curriculum \\
\hline & 2. Not in the curriculum \\
\hline & 3. 2 hours of class \\
\hline & 4. An elective course \\
\hline & 5. Language and culture contents supporting the course \\
\hline & 6. It should also be included in graduate curricula \\
\hline & 7. It should be a required course \\
\hline \multirow{3}{*}{$\begin{array}{l}\text { 2.Students' atti- } \\
\text { tudes towards the } \\
\text { course }\end{array}$} & 8. Students are willing to take the course \\
\hline & 9. Students should have preliminary information about the course. \\
\hline & 10. It is important to want to work in different fields. \\
\hline \multirow{3}{*}{$\begin{array}{l}\text { 3.Academics' } \\
\text { course-related } \\
\text { qualifications }\end{array}$} & 11. Theoretical competence of academics is important. \\
\hline & $\begin{array}{l}\text { 12. It is important for academics to have experience in the fields of medical tourism and } \\
\text { nursing. }\end{array}$ \\
\hline & 13. Relationship between academics and students' competence \\
\hline
\end{tabular}

14. It is important for academics to have experience in the field of pedagogy.

15. Including the course in the curriculum of private schools

16. Not only the medical tourism nursing course

17. School administrators finding the integration of the course insufficient

4.Studies on medical tourism nursing by Schools and Ministry of Health

18. School administrators finding the integration of the course into the transcultural nursing course insufficient

19. Finding studies carried out by Schools and the Ministry of Health insufficient

20. I do not know about the studies conducted by the Ministry of Health.

21. Scientific and academic approach of the Ministry of Health to the issue

22. Existence of a database

23. The concept of medical tourism is new to schools and they have just recently begun to address it. 


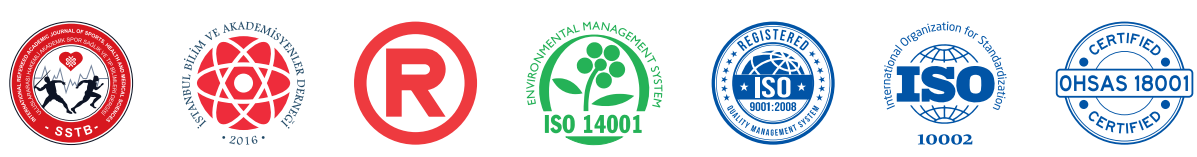

SSTB

www.sstbdergisi.com

International Refereed Academic Journal of Sports, Health and Medical Sciences

October - November - December Issue: 33 Fall Winter Semester Year: 2019

Uluslararası Hakemli Akademik Spor Sağlık ve Tıp Bilimleri Dergisi

Ekim - Kasım - Aralık Sayı: 33 Güz Kış Dönemi Yıl: 2019

ID:455 K:231

ISSN Print: 2146-8508 Online 2147-1711

(ISO 18001-OH-0090-13001706 / ISO 14001-EM-0090-13001706 / ISO 9001-QM-0090-13001706 / ISO 10002-CM-0090-13001706) (TRADEMARK)

(2015/04315- 2015-GE-18972)

\begin{tabular}{|c|c|}
\hline \multirow{5}{*}{$\begin{array}{l}\text { 5.Views and } \\
\text { expectations of } \\
\text { employment of } \\
\text { foreign nurses } \\
\text { in Turkey and of } \\
\text { their qualificati- } \\
\text { ons and compe- } \\
\text { tences }\end{array}$} & $\begin{array}{l}\text { 25. All we need to do is train nurses in our country and get them to work in this field after } \\
\text { they have developed the necessary skills }\end{array}$ \\
\hline & $\begin{array}{l}\text { 26. Foreign nurses' country of origin and education level matter. If they are suitable, they } \\
\text { can work here. }\end{array}$ \\
\hline & 27. Those with universal values and common nursing language can come and work here. \\
\hline & 28. Foreign nurses can work here if they have postgraduate qualification. \\
\hline & $\begin{array}{l}\text { 29. It will be sufficient if foreign nurses with a high level of foreign language proficiency, } \\
\text { clinical experience and high communication skills work in our country. }\end{array}$ \\
\hline \multirow{3}{*}{$\begin{array}{l}\text { 6.Views on } \\
\text { legal, educational } \\
\text { and scientific } \\
\text { infrastructure of } \\
\text { medical tourism } \\
\text { and nursing }\end{array}$} & $\begin{array}{l}\text { 30. Medical tourism and nursing are very new. Legal, educational and scientific infrast- } \\
\text { ructure is not enough. }\end{array}$ \\
\hline & $\begin{array}{l}\text { 31. Educational infrastructure has recently begun to be developed, therefore, it is insuffi- } \\
\text { cient for now. }\end{array}$ \\
\hline & demic studies have recently begun to be carried out, therefore, they are limited for \\
\hline
\end{tabular}

\section{Views on the position and adequacy of the course}

All academics emphasized that medical tourism nursing should be included in the curriculum. Below is a quote from A1:

\section{I think that medical tourism nursing is a} course that should be included in the curriculum of nursing schools, health schools and even midwifery schools.

\section{Academics' views on students' attitudes towards the course}

All academics, in general, stated that students would be willing to take that kind of course. Below is a quote from A9 regarding this:
If students are informed about course content, learning outcomes, and the importance of medical tourism/transcultural nursing as a condition of being a professional nurse, then they will be more willing to take the course.

\section{Academics' views on their own qualifica- tions on the course}

All academics stated that the theoretical knowledge level of academics teaching students medical tourism should be sufficient. A quote about the sub-themes from the interview is as follows:

It is important that this education is provided by people who have received training and worked in the field of medical tourism. May- 
International Refereed Academic Journal of Sports, Health and Medical Sciences October - November - December Issue: 33 Fall Winter Semester Year: 2019

Uluslararası Hakemli Akademik Spor Sağlık ve Tıp Bilimleri Dergisi

Ekim - Kasım - Aralık Sayı: 33 Güz Kış Dönemi Yıl: 2019 ID:455 K:231

ISSN Print: 2146-8508 Online 2147-1711

(ISO 18001-OH-0090-13001706 / ISO 14001-EM-0090-13001706 / ISO 9001-QM-0090-13001706 / ISO 10002-CM-0090-13001706) (TRADEMARK)

(2015/04315- 2015-GE-18972)

be they should do the same thing abroad as well. Academics in the field of medical tourism should also have pedagogical qualification and background knowledge... (A4)

4. Academics' views on studies on medical tourism nursing carried out by School Management and Ministry of Health

5 academics stated that it was mostly private schools that have developed more positive attitudes towards medical tourism and nursing course while 3 academics stated that school administrators have integrated the course as a subject matter into other courses but that they found this strategy insufficient. All academics found the studies on medical tourism and nursing conducted by the Ministry of Health inadequate.

\section{Academics' views and expectations of em-} ployment of foreign nurses in Turkey and of their qualifications and competences

5 academics stated that they did not object to the employment of foreign nurses in the field of medical tourism if they meet certain conditions while 3 academics emphasized the importance of country of origin and education level, and specified universal values and a common nursing language as prerequisites for employment. A quote about the sub-themes from the interview is as follows:
I am of the opinion that this service should be provided by nurses who have been trained in this field and have the necessary qualifications. (A1)

Those who were in favor of the employment of foreign nurses in Turkey made specific recommendations, such as having a master's degree and introduction of legal regulations.

Foreign nurses, especially those from agreement countries, who can speak foreign languages and are in tune with our culture can be employed in the field of medical tourism. But this should definitely be limited by legal regulations. (A7)

\section{Academics' views on legal, educational} and scientific infrastructure in the field of medical tourism and nursing

All academics stated that such work develops parallel to legal arrangements and policies, that medical tourism and nursing are very new concepts, and that the legal, educational and scientific infrastructure has not yet been established. A quote about the sub-themes from the interviews is given below:

\section{DISCUSSION}

The analysis shows that this study achieved optimal diversity. Academics expressed their views objectively about medical tourism and nursing education, and their role and significance. The findings are limited to the educa- 


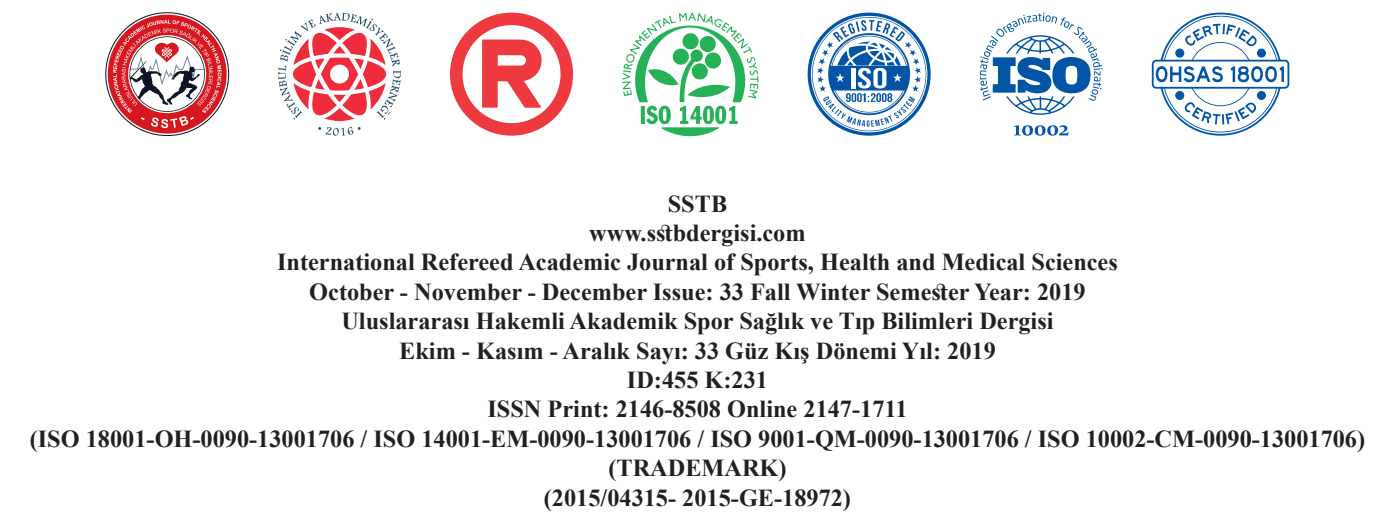

tional institution, which is actually a health faculty, involved in this study, therefore, it is recommended that similar studies be conducted in a number of faculties and universities in order to make generalizations about the current state of medical tourism and nursing education in Turkey.

This is the first study to address the issue of medical tourism and nursing education in Turkey. Therefore, there is no possibility of comparing and contrasting the results of this study with those of others. We believe that our results will provide guidance for further research.

The first theme drew attention to the need for educational structuring of medical tourism nursing. The fact that participants clearly specified the content of the course and the number of hours to be allocated to it indicates that these two factors play an important role in medical tourism nursing education and curriculum development.

The second theme addressed academics' views on students' attitudes towards the course and factors influencing their attitudes. Academics stated that students were willing to take courses on medical tourism nursing in any case and that providing students with preliminary information and course guidance would have a positive effect on their willingness. Research shows that possessing the power to guide stu- dents is critical and that motivation is one of the most important factors driving learning and enhancing students' engagement and achievement (KayaandBüyükkasap,2005:367-380; Vaismoradi et al., 2013:398-405; Sezgin et al., 2011:161-169; Erdem, 2007:77-81; Akbaba, 2006:343-361). This study also shows that students' attitudes towards the course depend on academics' guiding and motivating behavior. Herdman (2011:3-7) states that nursing education will evolve universally with technological and global health movements and qualified instructors. Seren et al. (2013:42-48) also express the importance of having a sufficient number of instructors to train nurses, which is also worthy of consideration.

Another theme dealt with the studies on medical tourism nursing conducted by schools and the Ministry of Health. There is a consensus among academics that studies on medical tourism nursing are inadequate and that educational and academic activities, and legal regulations fail to specify the job description and role of nurses in the field of medical tourism. Çevirme, Kaynak and Uğurlu (2014:4458) reported that only 8 health schools training nurses made arrangements about the course and that nurses could not make themselves heard in congresses and symposiums on medical tourism organized by the Ministry of Health. Both studies provide similar results and important clues about the shortcomings, 


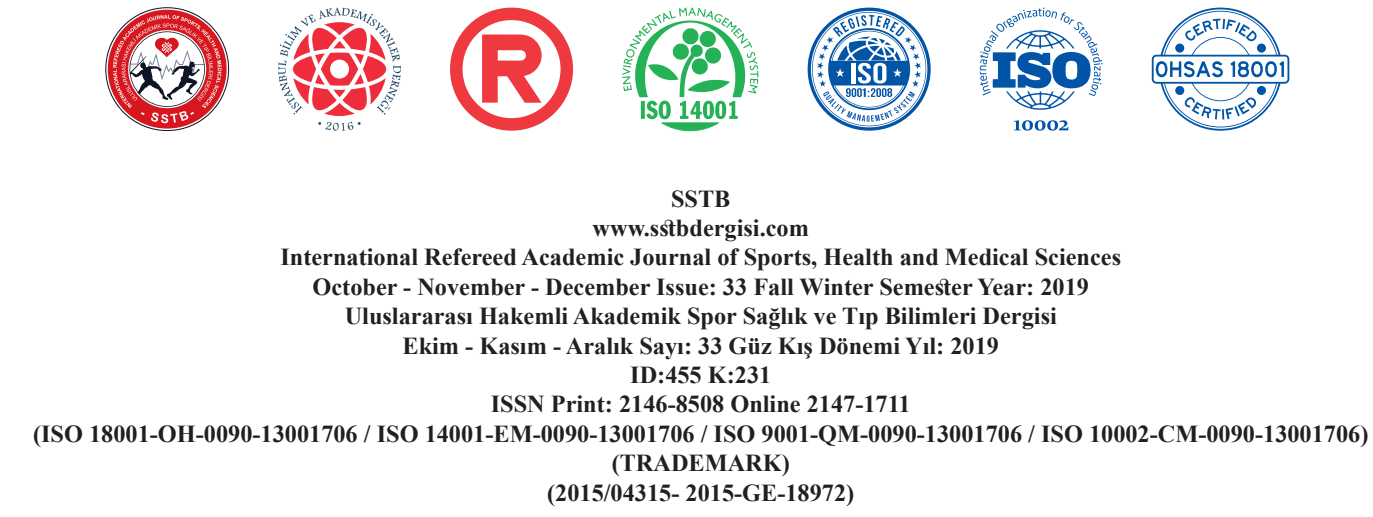

suggesting that all stakeholders of medical tourism nursing should increase the pace of their efforts.

Seren et al. (2013:42-48) report that $93.8 \%$ of academics are against the employment of foreign nurses. The fifth theme shows that academics in general object to the employment of foreign nurses in Turkey. However, some academics lean towards favoring the employment of foreign expert nurses who have adopted universal values. A few academics emphasize the importance of having a master's degree as a criterion for foreign nurses to be employed in Turkey. Differences in the way academics think about foreign nurse employment suggest that nationality or qualifications alone cannot be a critical factor.

The sixth theme addressed the issues that medical tourism and nursing is a nascent field and that the legal, educational and scientific infrastructure is far from adequate. In parallel with the literature, academics stated that health tourism in general and medical tourism in particular emerged in the 1990s and have so far made little progress in terms of nursing (Çevirme et al.,2014:44-58; İçöz, 2009:22572279).

\section{CONCLUSION}

This study, aiming to encourage further education and scientific research on medical tourism nursing course, shows that academics' knowl- edge, views and attitudes are of great significance for students to gain vocational qualifications.

Permanent and innovative agreements and arrangements should be made between the nursing schools and the Ministry of Health in order to solve the problems that arise from integrating the course into educational curricula. Services and resources should be made available to assist nurses in acquiring foreign languages, gaining clinical experience and developing effective communication skills in order to improve the field of medical tourism in Turkey. Long-term plans should be made to standardize and improve the education system in order to provide nurses with employment opportunities.

Determining qualifications alone is not enough to adapt education to the information age. Since it is imperative for educational institutions to evaluate their education systems and vocational competence of their graduates, and to implement necessary innovations and regulation (Sezgin et al., 2011:161-169), it is recommended that nurses who want to work in the field of medical tourism be evaluated in advance.

It is recommended that academics collectively explain the content and learning outcomes of courses before students make any course-related decisions. 
International Refereed Academic Journal of Sports, Health and Medical Sciences

October - November - December Issue: 33 Fall Winter Semester Year: 2019

Uluslararası Hakemli Akademik Spor Sağlık ve Tıp Bilimleri Dergisi

Ekim - Kasım - Aralık Sayı: 33 Güz Kış Dönemi Yıl: 2019 ID:455 K:231

ISSN Print: 2146-8508 Online 2147-1711

(ISO 18001-OH-0090-13001706 / ISO 14001-EM-0090-13001706 / ISO 9001-QM-0090-13001706 / ISO 10002-CM-0090-13001706) (TRADEMARK)

FINANCİAL SUPPORT AND SPONSORSHIP

Nil.

\section{CONFLİCTS OF İNTEREST}

There are no conflicts of interest.

\section{REFERENCES}

$\boldsymbol{A K B} \boldsymbol{A B} \boldsymbol{A}, \boldsymbol{S}$., (2006). Eğitimde motivasyon. Kazım Karabekir Eğitim Fakültesi Dergisi, 13: 343-361.

AYDIN, D., ŞEKER, S., ŞAHAN, S., (2011). Kamu Hastanelerinde Sağl1k Turizmi ve Turistin Sağlı̆̆ Uygulama Rehberi. Ankara, Türkiye: Sağlık Bakanlığı.

BEN-NATAN, M., BEN-SEFER, E., EHRENFELD, M., (2009). Medical Tourism: A New Role for Nursing?. The Online Journal of Issues in Nursing (OJIN), 14(3).

BOOKMAN, M.Z., BOOKMAN, K.R.,(2007).

Medical tourism in developing countries.

New York, USA: Palgrave Mac Millian Deregulation, ss.1-29.

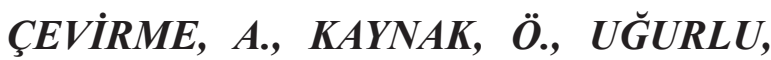
N., (2014). Medikal Turizm: Hemşirenin Yeni Rolü Ve Durumu. International Refereed Academic Journal of Sports, 13(4): 44-58.
DONNELLY, L., SAWER, P. Record numbers go abroad for health. The Telegraph, Retrieved October 292007.

ERDEM, $\boldsymbol{A}$. R., (2007). Öğretim üyesinin bilim insanı yetiştirme sorumluluğu ve bu sorumluluğun gerektirdiği mesleki etik. Akademik Dizayn Dergisi, 1(2): 77-81.

EVANS, R., (2008). Ethnocentrism is an unacceptable rationale for healthcare policy: A critique of transplant tourism position statements. American Journal of Transplantation, 8(6): 1089-1095.

FORGIONE, D.A., SMITH, P.C., (2007). Medical tourism and its impact on the US health care system. Journal of Health Care Finance, 34(1): 27-35.

HERDMAN, E. A., (2011). 20. Yüzyıl Eğitimini Kullanarak 21. Yüzyılın Zorluklarıyla Yüzleşmek: Hemşirelik Örneği. Hemşirelikte Eğitim ve Araştırma Dergisi, 8 (3): 3-7.

HOROWITZ, M.D., ROSENSWEIG, J.A., JONES, C.A., (2007). Medical tourism: Globalization of the healthca.re marketplace. Medscape General Medicine, 9(4): $33-41$.

IÇÖZ, O., (2009). Sağl1k Turizmi Kapsamında Medikal (tıbbi) Turizm ve Türkiye'nin Olanakları. Journal of Yasar University, 4(14): 2257-2279. 
SSTB

www.sstbdergisi.com

International Refereed Academic Journal of Sports, Health and Medical Sciences

October - November - December Issue: 33 Fall Winter Semester Year: 2019

Uluslararası Hakemli Akademik Spor Sağlık ve Tıp Bilimleri Dergisi

Ekim - Kasım - Aralık Sayı: 33 Güz Kış Dönemi Yıl: 2019 ID:455 K:231

ISSN Print: 2146-8508 Online 2147-1711

(ISO 18001-OH-0090-13001706 / ISO 14001-EM-0090-13001706 / ISO 9001-QM-0090-13001706 / ISO 10002-CM-0090-13001706) (TRADEMARK)

(2015/04315- 2015-GE-18972)

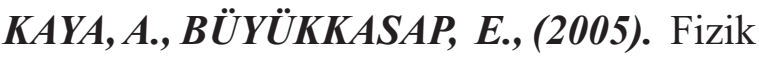
Öğretmenliği Programı Öğrencilerinin Profilleri, Öğretmenlik Mesleğine Yönelik Tutum ve Endişeleri: Erzurum Örneği, Kastamonu Eğitim Dergisi, 12(2): 367-380.

SEREN, A.K.H., BACAKSIZ, F.E., YILDIRIM, A., (2013). Bir Hemşirelik Fakültesindeki Öğretim Elemanı ve Öğrencilerin Yabancı Hemşire İstihdamına İlişkin Görüşleri. Hemşirelikte Eğitim ve Araştırma Dergisi, 10(3): 42-48.

SEZGIN, F., KAVGACI, H., KILINÇ, A.Ç., (2011). Türkiye'de Eğitim Yönetimi ve Denetimi Lisansüstü Öğrencilerinin Öz
Değerlendirilmesi, Journal of Higher Education and Science, 1(3): 161-169.

ÖZDEN, M.Y., DURDU, L. Eğitimde Üretim Tabanlı Çalışmalar İçin Nitel Araştırma Yöntemleri. Anı Yayıncılık, ss.1-182.

VAISMORADI M, TURUNEN H, BONDAS

T. (2013). Content analysis and thematic analysis: Implications for conducting a qualitative descriptive study. Nursing Health Science, 15(3): 398-405.

\section{INTERNET RESOURCES}

http://www.yok.gov.tr/web/guest/universitelerimiz (E.T. 10.12.2018) 